\title{
Promoting Entrepreneurial Commitment: The Benefits of Interdisciplinarity
}

\author{
Franziska Brodack and Anna Sinell
}

\author{
(' Individual commitment to a group effort - that is") \\ what makes a team work, a company work, a \\ society work, a civilization work.
}

Vince Lombardi (1913-1970)

American Football Player and Head Coach

\begin{abstract}
This article is the first to examine the relationship between interdisciplinarity and entrepreneurial commitment in academic spin-offs. Building on literature on interdisciplinarity, academic entrepreneurship, and entrepreneurial intention, we analyzed the development of nine interdisciplinary spin-off teams comprising expertise from science, industry, and design. Our findings suggest that interdisciplinary teams engage with their ideas, maintain productive interaction, and successfully implement these ideas. Subjects in this study thoroughly developed their project proposals and implementation strategies by examining them from multiple angles. They believed not only in the value of these projects, but in their own ability to see them through. They found one another's contributions highly inspirational and experienced a strong sense of responsibility and motivation. Communication within the teams was well managed, and tasks were clearly defined and distributed. Based on our findings, we put forward a number of propositions about the positive effects of interdisciplinarity on entrepreneurial commitment and conclude with implications for future research and practice.
\end{abstract}

\section{Introduction}

In innovation-driven economies, the transfer of scientific findings to industry has great economic and political significance. Academic entrepreneurship is one particularly potent form of such transfer (Grimaldi et al., 2011; Siegel \& Wright, 2015). Recognizing its benefits, European decision makers in academia, industry, and government increasingly regard academic entrepreneurship as the third "academic mission" and continue to introduce wide-ranging support initiatives. Nonetheless, transfer performance in Europe still lags behind that of universities in the United States (Audretsch \& Göktepe-Hultén, 2015).

Academics might experience particular difficulty in overcoming the challenges of entrepreneurship because they often regard industry as a completely alien environment and because they lack business-related resources and skills (Franklin et al., 2001; Rasmussen \&
Wright, 2015; Siegel \& Wright, 2015; Sinell et al., 2015). Even when they do successfully initiate spin-offs, they rarely invite non-scientific specialists to join (Ensley \& Hmieleski, 2005; Franklin et al., 2001; Knockaert et al., 2011). At the same time, teams composed of members with different areas of expertise and networks might more successfully transform scientific findings into marketable products and services (Knockaert et al., 2011).

To bridge the gap between mere entrepreneurial intention and actual entrepreneurial activities, the concept of entrepreneurial commitment plays a significant role (Fayolle et al., 2011; Malewicki, 2005). Studies found a positive impact of entrepreneurial commitment on start-up performance (Tasnim \& Singh, 2016; De Clercq et al., 2009), new venture formation (Fayolle, 2007), and new product development (Schmidt \& Calantone, 2002). Nevertheless, so far, little research has been done on the factors that promote entrepreneurial commitment (Fayolle et al., 2011). 


\section{Promoting Entrepreneurial Commitment: The Benefits of Interdisciplinarity}

Franziska Brodack and Anna Sinell

\section{Theoretical Framework}

Following Auer and Walter (2009), we define academic spin-offs as independent business entities that are founded by or with the help of employees of publicly funded research organizations in order to commercialize scientific findings and technological products.

In comparison to mere entrepreneurial intention (Crant, 1996; Fayolle et al., 2011), entrepreneurial commitment more frequently results in entrepreneurial activities (Erikson, 2002; Vohora et al., 2004). Entrepreneurial commitment is known to be crucial "for a potential venture to be taken forward from a vision that the researcher has created in his mind, to the formation of a running business" (Parente \& Feola, 2013). Entrepreneurial commitment starts with a considerable investment of time, energy, and resources, including financial, intellectual, relational, and emotional resources (Fayolle et al., 2011; Parente \& Feola, 2013).

In the context of organizational behaviour, commitment is indicated by attachment to, identification with, and involvement in the organization's projects (affective), willingness to expend significant effort (normative), and a strong desire to belong in the long term (continuance) (Meyer \& Herscovitch, 2001; Mowday et al., 1979). Tasnim and Singh (2016) extended the work of Meyer and Herscovitch (2001) in the context of entrepreneurial activities. Accordingly, entrepreneurial commitment is shaped by seven separate constructs that influence the three components of commitment: i) affective commitment is influenced by the entrepreneur's passion, values, and personality; ii) normative commitment is shaped by the entrepreneurs internalized norms, responsibility and righteousness; and iii) continuous commitment is affected by the entrepreneur's investments in the project and lack of alternatives (Tasnim et al., 2016). A study with over 400 startups revealed a positive effect of affective commitment and normative commitment on the development of entrepreneurial commitment, indicating that the entrepreneur's strong emotional attachment to their venture and desire for it to succeed will lead to a higher level of entrepreneurial commitment. Likewise, the entrepreneur's perceived obligation resulting from the internalization of norms, the receipt of benefits that induces a need to reciprocate or stimulates the acceptance of responsibilities, positively affects the development of entrepreneurial commitment (Tasnim \& Singh, 2016; Tasnim et al., 2014).
Further indicators for the factors that promote entrepreneurial commitment can be found in the literature of entrepreneurial intention. Because entrepreneurial commitment can be considered to supplement entrepreneurial intention (Erikson, 2002), relevant existing models of the latter can be expanded to examine the former (Parente \& Feola, 2013). Almost all such models include the perceived (internal and external) desirability of a potential startup and its perceived feasibility (Ajzen, 1991; Bird, 1998; Krueger et al., 2000; Shapero \& Sokol, 1982).

Literature on individual entrepreneurs shows that entrepreneurs who are curious to explore the new, are innovative, are proactive, and are able to take risks are more likely to engage in entrepreneurial activities (Langkamp et al., 2012; Kollmann et al., 2007). Regarding the factors that promote founding teams to engage in the venturing process, little research has been done so far. A study by Boeker (1997) investigating managerial teams found that heterogeneous teams are more likely to manifest entrepreneurial and innovative behaviours and enter new product markets than homogeneous teams. Meanwhile, studies in innovation research have shown the different ways in which interdisciplinary teams can benefit the innovation process and outperform more homogenous teams (Harrison \& Klein, 2007; Nickerson \& Zenger, 2004; Page, 2007). A greater variety of knowledge bases, methods, and mindsets, resulting from diversity in educational and professional backgrounds, typically lead to more informed and considered decisions (Pelled et al., 1999) and might be particularly useful early in the innovation process to master the challenges of technology development, marketing, product definition, and business and financial analysis (Cooper 1979; Montoya-Weiss, 1994). Teams that include both academics and professionals with diverse backgrounds have been shown to successfully navigate startups through the initial, and often the most challenging, development stages (Knockaert et al., 2011; Rasmussen \& Wright, 2015; Visintin \& Pittino, 2014). Therefore, we argue that an interdisciplinary team composition, due to the greater variety of competencies, perspectives, and knowledge, can support the perceived desirability and perceived feasibility of aspiring entrepreneurs, thus promoting entrepreneurial commitment.

Fayolle and colleagues (2011) argue that greater operational knowledge of commitment phenomenon should improve the quality of startup support. Research on entrepreneurship has thus far devoted little attention to such factors, particularly team composition. To address 


\section{Promoting Entrepreneurial Commitment: The Benefits of Interdisciplinarity}

Franziska Brodack and Anna Sinell

this gap, we examined the relationship between interdisciplinarity and performance by focusing on the following research question: Does interdisciplinarity in academic spin-offs promote entrepreneurial commitment, and if so, how?

\section{Method}

We examined a six-month spin-off incubator hosted by a leading, publicly funded European research institute and ultimately involving a total of 32 potential founders. They were 17 men $(53 \%)$ and 15 women (47\%) and were on average 29.28 years old ( $\mathrm{SD}=4.81$ ). Eight were students. Twenty-four were employed or self-employed. The incubator resulted in nine teams, each with its own project proposal, involving a total of 26 individuals: ten designers, nine scientists, and seven business managers. Three different coaches and a number of experts from different fields provided ongoing advice and training. An external jury evaluated the results.

The case study approach (Eisenhardt, 1989; Eisenhardt \& Graebner, 2007) was employed because its inductive nature is particularly suited to qualitative data analysis in addressing previously unexamined questions (Yin, 2009). Each team provided one case as shown in Table 1.

The data was gathered from 60 semi-structured interviews, each lasting between 20 and 60 minutes. Twentytwo participants were interviewed midway through: 16 upon completing and 14 upon leaving the incubator. Participants were typically interviewed first midway through and then upon completing or leaving the incubator. Coaches and members of the jury were interviewed only at the end.

Table 1. The nine interdisciplinary cases examined in this study

\begin{tabular}{lllcc}
\hline Case & Technology & $\begin{array}{l}\text { Product or } \\
\text { Service }\end{array}$ & $\begin{array}{l}\text { Number of } \\
\text { Founders }\end{array}$ & $\begin{array}{c}\text { Industry } \\
\text { Experience }\end{array}$ \\
\hline ASO1 & Medical device & Product & 2 & Yes \\
\hline ASO2 & Damping panel & Product & 4 & No \\
\hline ASO3 & Psychological gaming & Service & 4 & Yes \\
\hline ASO4 & $\begin{array}{l}\text { Patient management } \\
\text { service }\end{array}$ & Service & 5 & Yes \\
\hline ASO5 & Data mapping & Service & 3 & No \\
\hline ASO6 & $\begin{array}{l}\text { Smarthardware } \\
\text { vendor }\end{array}$ & Service & 1 & Yes \\
\hline ASO7 & Medical device & Product & 3 & No \\
\hline ASO8 & Healthcare app & Service & 2 & No \\
\hline ASO9 & Healthcare device & Product & 2 & No \\
\hline
\end{tabular}

timreview.ca
Interview transcripts were qualitatively analyzed with the help of Mayring's method (Mayring, 2010). Other data such as field notes, one-pagers, business plans, and pitch decks were added to the transcripts and provided valuable context-specific information (Ritchie et al., 2013).

In the next section, based on our findings, we put forward a number of propositions about the positive effects of interdisciplinarity on entrepreneurial commitment.

\section{Findings and Propositions}

\section{Engagement with ideas}

Every successful startup begins with a good idea. The more founders believe in their project, the greater their commitment (Cooper et al., 1988). Our findings suggest that, by embracing a wider variety of perspectives, members of interdisciplinary teams are likely to experience high levels of motivation and dedication to their ideas, which leads to stronger affective commitment and higher perceived desirability of the venture project.

In addition to personality traits, social networks, and scientific expertise, an understanding of markets, consumer needs, and customer service strategies can help uncover business opportunities (Ardichvili et al., 2003). Potential founders in this study experienced the opportunity to discover different, previously unfamiliar mindsets and methods as inspirational, motivating, and beneficial to idea development. They utilized their combined knowledge to examine multiple aspects of both their proposed projects and implementation strategies by accounting for three different perspectives product, market, and consumer.

Six of the nine teams admitted new members with additional expertise immediately after the incubator process had begun, which encouraged these teams to streamline or even substantially alter their original ideas: "Right away [...], what I definitely found very useful and exciting was looking at the idea more closely and asking ourselves: so, is it really that good, or do we need to keep working on it?" (ASO1 member) In particular, the approaches introduced by the designers in these teams helped all members better understand the customer perspective.

Founders regarded their project proposals as shared visions produced by team effort and expressed a strong belief in their value: "Toward the end, it got to be really exciting, working on this idea that could really fill a

timreview.ca 


\section{Promoting Entrepreneurial Commitment: The Benefits of Interdisciplinarity}

Franziska Brodack and Anna Sinell

niche and then even be up and running someday. Suddenly, you are totally into it, with all your passion." (ASO1 member) Members of the teams that exhibited lower entrepreneurial commitment by leaving the project (ASO6, ASO7, and ASO8) explained their decision by the lack of necessary skills, leading to a loss of confidence in their project: "But the reason not to pitch to the jury was, in the first place, that the idea just wasn't ready. And it was a huge factor that the technological knowhow, for the hardware that we'd pictured, it just wasn't there, didn't exist. And that would've been key somehow." (ASO8 member)

Based on these findings, we propose the following:

Proposition 1: Interdisciplinarity increases identification and engagement with ideas, thus promoting entrepreneurial commitment.

\section{Implementation}

The more aspiring entrepreneurs believe in their ability to navigate the challenges of founding, the greater their commitment (Goethner et al., 2012). Our findings suggest that, through their combined knowledge, interdisciplinary teams are particularly likely to master such challenges and obtain higher levels of perceived feasibility of the venturing project: "Because the responsibilities were assigned this way, [...] nothing was unmanageable... because yes, because we had it covered." (ASO4 member)

Various teams exemplified how particular combinations of skills might be necessary for innovations to not only be proposed, but advanced. In ASO3, a psychologist's idea for a psychotherapeutic online game could not take form until a game developer created a demo and a project manager formulated a business plan. Those teams that left the incubator needed to do so exactly because they did not "have it covered." As one interviewee stated, "For this really crucial [managerial] task [...], we would need someone. Otherwise it just won't work. It's just not my area of expertise, absolutely not." (ASO6 member)

Based on these findings, we propose the following:

Proposition 2: Interdisciplinarity increases the likelihood of ideas being implemented, thus promoting entrepreneurial commitment.

\section{Teamwork}

Teamwork is the engine of entrepreneurship. Functional interaction increases entrepreneurial commitment
(Glew, 2012), while high levels of disagreement cause startups to fail (CBinsights, 2014; Kummer et al., 2016). Our findings suggest that members of interdisciplinary teams are likely to maintain productive teamwork through i) good communication strategies and ii) clear distribution of tasks.

While explaining ideas to their teammates, potential founders in this study deliberately used basic terms, accessible regardless of background. Some teams (ASO2, ASO3, ASO7, and ASO9) originally experienced communication barriers due to the use of professional jargon and took this as an opportunity not only to reach mutual understanding, but to further streamline communication: "Everyone brings their own field with them and that's great. But we always try to turn it down a notch to say it again, but more simply, really, less complex, to get everyone on the same page. It's important that noone feels excluded at the end." (ASO9 member)

Members of ASO1, ASO2, and ASO8 discovered that simple charts and sketches can sometimes best convey complex specifics and engage others in the subject at hand: "So that whole fungus development process, no mysteries to me there, because of my biology background. But for the others it was [hard] sometimes. So it took forever. But when we drew this cutesy little picture, then it finally clicked. So this visualization was actually an important communication tool for us." (ASO2 member)

Because of differences in background, participants felt that, in order to convey their own perspectives clearly, they first needed to better understand those of their teammates: "When I talk about findings in psychology, I immediately explain why: why it could actually be important for the finances or design. We try to speak each other's languages, I'd say. [...] We look at it from one another's point of view." (ASO3 member)

Because founders had their particular areas of expertise, tasks within the teams were clearly defined. This clear task distribution not only continued to promote constructive communication, but led to high levels of appreciation for one another's backgrounds and contributions: "And each and everyone feels valued because they have their own areas of responsibility in which they get to make decisions. And that's good, that's the way it should be, I believe." (ASO4 member)

In addition, high levels of self-confidence and a strong sense of responsibility could be observed: "An interdisciplinary team makes you more aware of your own com- 


\section{Promoting Entrepreneurial Commitment: The Benefits of Interdisciplinarity}

Franziska Brodack and Anna Sinell

petence. When I just hang out with biologists, they are all experts in their mini-fields, and I am an expert in my mini-field. And that makes me feel so small sometimes because the others also know a lot. But here [...], [here] I am officially 'the expert'. And that boosts my confidence.” (ASO2 member)

The experienced appreciation by other teammates and perceived responsibility for their respective field of expertise lead to higher levels of normative commitment. Based on these findings, we propose the following:

Proposition 3a: Interdisciplinarity leads to good communication strategies, thus promoting entrepreneurial commitment.

Proposition 3b: Interdisciplinarity leads to clear task distribution and a strong sense of responsibility, thus promoting entrepreneurial commitment.

\section{Conclusions}

Thus far, little research has been done on entrepreneurial commitment within academic spin-offs and the factors that promote it (Fayolle et al., 2011). The goal of this study was to examine the effects of interdisciplinarity on entrepreneurial commitment and derive first propositions on the relationship between the two constructs.

Our findings suggest that teams that exhibit a greater variety of knowledge bases, methods, and mindsets which we consider interdisciplinary - are likely to engage with their ideas, maintain productive interaction, and successfully implement these ideas. Potential spinoff founders in this study thoroughly developed both their project proposals and implementation strategies by examining them from multiple angles. They believed in the value of their projects and their own ability to master the challenges of entrepreneurship, thus expressing high levels of perceived desirability and feasibility (Ajzen, 1991). They experienced high levels of appreciation for one another's contributions and a strong sense of responsibility and motivation leading to high levels of normative commitment (Tasnim et al. 2016). Given that every team member had their own field of expertise, tasks were clearly defined and distributed within teams. Team members quickly overcame the barriers of professional jargon and developed effective communication strategies.

Academic spin-offs particularly benefit from interdisciplinarity because the scientific perspectives, know- ledge, and methods of single academics are challenged within the team. Therefore, ideas can be further developed and streamlined. When academics are open to such discussions, promising business opportunities with high levels of engagement can arise. Due to the combination of theoretical and practical knowledge within the teams, interdisciplinary academic spin-offs are more likely to transform ideas from a mere theoretical to a more application-oriented level. Especially against the background that academic spin-offs often lack business and market-related knowledge, interdisciplinarity leads to higher levels of perceived feasibility. The ability to clearly communicate a startup idea is crucial for a new venture. In interdisciplinary teams, academics are forced to simplify scientific language in order to better communicate. This is also very beneficial when communicating the business idea to external stakeholders.

All of the above suggests that interdisciplinary teams might be particularly likely both to make a commitment to their spinoffs and to uncover good commercialization opportunities. Research institutions that wish to encourage academic entrepreneurship should therefore consider inviting non-scientific specialists to participate and integrating expertise from different research fields early on in the research process.

Furthermore, our findings confirm the importance of team composition for venture capitalist's investment decisions (Gorman \& Sahlman, 1989; Muzyka et al., 1996; Silva, 2004). Literature shows that venture capitalists prefer to invest in startups with high-quality teams (Silva, 2004) comprising entrepreneurs with industryrelated competences and heterogeneous educational backgrounds (Franke et al., 2008). Confirming the importance of interdisciplinary startup teams, our study indicates that, particularly in early stages of the venturing process, interdisciplinary teams are more likely to develop high levels of entrepreneurial commitment and are therefore more likely to establish and maintain a successful startup company. We therefore suggest that venture capitalists should consider a certain degree of heterogeneity within the composition of startup teams in order to foster team members commitment and avoid potential drop-outs.

Our study is not without limitations. Further research needs to establish whether the positive effects identified above can be observed not only during the early stages of spin-off development, as was the case in this study, but throughout their existence. Although all subjects had the opportunity to use the resources of the 


\section{Promoting Entrepreneurial Commitment: The Benefits of Interdisciplinarity}

\section{Franziska Brodack and Anna Sinell}

host research institute, such as facilities, materials, and networks, only one was actually employed there. Future studies might focus on more "typical" spin-offs where academic members come from the same organization, or they might compare interdisciplinary and more homogenous groups.

\section{Acknowledgements}

This article was developed from a paper presented at the ISPIM Innovation Conference in Vienna, Austria, June 18-21, 2017. ISPIM (ispim-innovation.com) - the International Society for Professional Innovation Management - is a network of researchers, industrialists, consultants, and public bodies who share an interest in innovation management.

\section{About the Authors}

Franziska Brodack is Research Fellow at the Fraunhofer Center for Responsible Research and Innovation in Berlin, Germany. Her current projects focus on academic spin-off creation and the utilization of inter- and transdisciplinary teams for technology and knowledge transfer. Franziska holds a Master's degree in Business Administration from the Brandenburg University of Technology in Germany.

Anna Sinell is a PhD Candidate at the Technical University of Berlin, Germany, and a Research Fellow at the Fraunhofer Center for Responsible Research and Innovation. Her research focus is the transfer of knowledge and technology between different actors in innovation ecosystems. She is currently finishing her $\mathrm{PhD}$ thesis on strategies to foster academic entrepreneurship at research institutions.

\section{References}

Audretsch, D. B., \& Göktepe-Hultén, D. 2015. University Patenting in Europe. In A. N. Link, D. S. Siegel, \& M. Wright (Eds.), The Chicago Handbook of University Technology Transfer and Academic Entrepreneurship: 188-217. Chicago, IL: University of Chicago Press.

Ajzen, I. 1991. The Theory of Planned Behavior. Organizational Behavior and Human Decision Processes, 50(2): 179-211. http://doi.org/10.1016/0749-5978(91)90020-T

Ardichvili, A., Cardozo, R., \& Ray, S. 2003. A Theory of Entrepreneurial Opportunity Identification and Development. Journal of Business Venturing, 18(1): 105-123. http://doi.org/10.1016/S0883-9026(01)00068-4

Auer, M., \& Walter, A. (Eds.). 2009. Academic Entrepreneurship: Unternehmertum in der Forschung (1st ed.). Wiesbaden, Germany: Gabler Verlag.

Bird, B. 1988. Implementing Entrepreneurial ideas: The Case for Intention. Academy of Management Review, 13(3): 442-453. http://doi.org/10.5465/AMR.1988.4306970

Boeker, W. 1997. Strategic Change: The Influence of Managerial Characteristics and Organizational Growth. Academy of Management Journal, 40(1): 152-170.

CBinsights. 2014. The Top 20 Reasons Startups Fail. New York: CB Insights.

https://www.cbinsights.com/research-reports/The-20-ReasonsStartups-Fail.pdf

Cooper, A. C., Woo, C. Y., \& Dunkelberg, W. C. 1988. Entrepreneurs' Perceived Chances for Success. Journal of Business Venturing, 3(2): 97-108. https://doi.org/10.1016/0883-9026(88)90020-1

Cooper, R. G. 1979. The Dimensions of Industrial New Product Success and Failure. Journal of Marketing, 43(3): 93-103. http://doi.org/10.2307/1250151

Crant, J. M. 1996. The Proactive Personality Scale as a Predictor of Entrepreneurial Intentions. Journal of Small Business Management, 34(3): 42-49.

De Clercq, D., Menzies, T. V., Diochon, M., \& Gasse, Y. 2009. Explaining Nascent Entrepreneurs' Goal Commitment: An Exploratory Study. Journal of Small Business \& Entrepreneurship, 22(2): 123-139.

Eisenhardt, K. M. 1989. Building Theories from Case Study Research. Academy of Management Review, 14(4): 532-550. http://doi.org/10.5465/AMR.1989.4308385

Eisenhardt, K. M., \& Graebner, M. E. 2007. Theory Building from Cases: Opportunities and Challenges. Academy of Management Journal, 50(1): 25-32. http://doi.org/10.5465/AMJ.2007.24160888

Ensley, M. D., \& Hmieleski, K. M. 2005. A Comparative Study of New Venture Top Management Team Composition, Dynamics and Performance between University Based and Independent HighTechnology New Ventures. Research Policy, 34(7): 1091-1105. http://doi.org/10.1016/j.respol.2005.05.008

Erikson, T. 2002. Entrepreneurial Capital: The Emerging Venture's Most Important Asset and Competitive Advantage. Journal of Business Venturing, 17(3): 275-290. http://doi.org/10.1016/S0883-9026(00)00062-8 


\section{Promoting Entrepreneurial Commitment: The Benefits of Interdisciplinarity}

\section{Franziska Brodack and Anna Sinell}

Fayolle, A. 2007. Entrepreneurship and New Value Creation: The Dynamic of the Entrepreneurial Process. Cambridge, UK: Cambridge University Press.

Fayolle, A., Basso, O., \& Tornikoski, E. T. 2011. Entrepreneurial Commitment and New Venture Creation: A Conceptual Exploration. In K. Hindle \& K. Klyver (Eds.), Handbook of Research on New Venture Creation: 160-182. Cheltenham, UK: Edward Elgar.

Franke, N., Gruber, M., Harhoff, D., \& Henkel, J. 2008. Venture Capitalists' Evaluations of Start-Up Teams: Trade-Offs, Knock-Out Criteria, and the Impact of VC Experience. Entrepreneurship Theory and Practice, 32(3): 459-483.

http://doi.org/10.1111/j.1540-6520.2008.00236.x

Franklin, S. J., Wright, M., \& Lockett, A. 2001. Academic and Surrogate Entrepreneurs in University Spin-Out Companies. The Journal of Technology Transfer, 26(1): 127-141.

http://doi.org/10.1023/A:1007896514609

Glew, D. J. 2012. Effects of Interdependence and Social InteractionBased Person-Team Fit. Administrative Sciences, 2(4): 26-46. http://doi.org/10.3390/admsci2010026

Goethner, M., Obschonka, M., Silbereisen, R. K., \& Cantner, U. 2012. Scientists' Transition to Academic Entrepreneurship: Economic and Psychological Determinants. Journal of Economic Psychology, 33(3): 628-641.

http://doi.org/10.1016/j.joep.2011.12.002

Gorman, M., \& Sahlman, W. A. 1989. What Do Venture Capitalists Do? Journal of Business Venturing, 4(4): 231-248. https://doi.org/10.1016/0883-9026(89)90014-1

Grimaldi, R., Kenney, M., Siegel, D. S., \& Wright, M. 2011. 30 Years After Bayh-Dole: Reassessing Academic Entrepreneurship. Research Policy, 40(8): 1045-1057.

http://doi.org/10.1016/j.respol.2011.04.005

Harrison, D. A., \& Klein, K. J. 2007. What's the Difference? Diversity Constructs as Separation, Variety, or Disparity in Organizations. Academy of Management Review, 32(4): 1199-1228. http://doi.org/10.5465/AMR.2007.26586096

Knockaert, M., Ucbasaran, D., Wright, M., \& Clarysse, B. 2011. The Relationship between Knowledge Transfer, Top Management Team Composition, and Performance: The Case of Science-Based Entrepreneurial Firms. Entrepreneurship Theory and Practice, 35(4): 777-803.

http://doi.org/10.1111/j.1540-6520.2010.00405.x

Kollmann, T., Christofor, J., \& Kuckertz, A. 2007. Explaining Individual Entrepreneurial Orientation: Conceptualisation of a CrossCultural Research Framework. International Journal of Entrepreneurship and Small Business, 4(3): 325-340. https://doi.org/10.1504/IJESB.2007.013255

Krueger, N. F., Reilly, M. D., \& Carsrud, A. L. 2000. Competing Models of Entrepreneurial Intentions. Journal of Business Venturing, 15(56): 411-432.

http://doi.org/10.1016/S0883-9026(98)00033-0

Kummer, J., Funke, T., Amrheim, A.-G., \& Müller, M. 2016. Gründungen scheitern nicht am Team, sondern im Team: Studie zu Herausforderungen für Startup-Teams. Berlin: Federal Ministry of Economics and Technology (Germany).

https://www.rkw-

kompetenzzentrum.de/gruendung/studie/gruendungen-

scheitern-nicht-am-team-sondern-im-team/
Langkamp Bolton, D., \& Lane, M. D. 2012. Individual Entrepreneurial Orientation: Development of a Measurement Instrument. Education + Training, 54(2/3): 219-233. https://doi.org/10.1108/00400911211210314

Link, A. N., Siegel, D. S., \& Wright, M. 2015. The Chicago Handbook of University Technology Transfer and Academic Entrepreneurship. Chicago, IL: The University of Chicago Press.

Malewicki, D. S. 2005. Member Involvement in Entrepreneur Network Organizations: The Role of Commitment and Trust. Journal of Developmental Entrepreneurship, 10(02): 141-166. http://doi.org/10.1142/S1084946705000112

Mayring, P. 2010. Qualitative Inhaltsanalyse: Grundlagen und Techniken. Weinheim, Germany: Beltz.

Meyer, J. P., \& Herscovitch, L. 2001. Commitment in the Workplace: Toward a General Model. Human Resource Management Review, 11(3): 299-326. http://doi.org/10.1016/S1053-4822(00)00053-X

Montoya-Weiss, M. 1994. Determinants of New Product Performance: A Review and Meta-Analysis. Journal of Product Innovation Management, 11(5): 397-417. http://doi.org/10.1016/0737-6782(94)90029-9

Mowday, R. T., Steers, R. M., \& Porter, L. W. 1979. The Measurement of Organizational Commitment. Journal of Vocational Behavior, 14(2): 224-247. http://doi.org/10.1016/0001-8791(79)90072-1

Muzyka, D., Birley, S., \& Leleux, B. 1996. Trade-Offs in the Investment Decisions of European Venture Capitalists. Journal of Business Venturing, 11(4): 273-287. https://doi.org/10.1016/0883-9026(95)00126-3

Nickerson, J. A., \& Zenger, T. R. 2004. A Knowledge-Based Theory of the Firm? The Problem-Solving Perspective. Organization Science, 15(6): 617-632. https://doi.org/10.1287/orsc.1040.0093

Page, S. E. 2007. The Difference: How the Power of Diversity Creates Better Groups, Firms, Schools, and Societies. Princeton, NJ: Princeton University Press.

Parente, R., \& Feola, R. 2013. Entrepreneurial Intent and Entrepreneurial Commitment of Young Researchers. International Journal of Technology Management \& Sustainable Development, 12(2): 155-166.

http://doi.org/10.1386/tmsd.12.2.155_1

Pelled, L. H., Eisenhardt, K. M., \& Xin, K. R. 1999. Exploring the Black Box: An Analysis of Work Group Diversity, Conflict, and Performance. Administrative Science Quarterly, 44(1): 1-28. http://doi.org/10.2307/2667029

Rasmussen, E., \& Wright, M. 2015. How Can Universities Facilitate Academic Spin-Offs? An Entrepreneurial Competency Perspective. The Journal of Technology Transfer, 40(5): 782-799. http://doi.org/10.1007/s10961-014-9386-3

Ritchie, J., Lewis, J., Nicholls, C. M., \& Ormston, R. 2013. Qualitative Research Practice: A Guide for Social Science Students and Researchers (2nd ed.). Thousand Oaks, CA: Sage Publications.

Schmidt, J. B., \& Calantone, R. J. 2002. Escalation of Commitment during New Product Development. Journal of the Academy of Marketing Science, 30(2): 103-118.

https://doi.org/10.1177/03079459994362 


\section{Promoting Entrepreneurial Commitment: The Benefits of Interdisciplinarity}

Franziska Brodack and Anna Sinell

Shapero, A., \& Sokol, L. 1982. The Social Dimensions of Entrepreneurship. In C. Kent, D. L. Sexton, \& K. H. Vesper (Eds.), Encyclopedia of Entrepreneurship: 72-90. Englewood Cliffs, NJ: Prentice Hall.

Siegel, D. S., \& Wright, M. 2015. Academic Entrepreneurship: Time for a Rethink? British Journal of Management, 26(4): 582-595. http://doi.org/10.1111/1467-8551.12116

Silva, J. 2004. Venture Capitalists' Decision-Making in Small Equity Markets: A Case Study Using Participant Observation. Venture Capital, 6(2-3): 125-145. http://doi.org/10.1080/13691060410001675974

Sinell, A., Heidingsfelder, M., \& Schraudner, M. 2015. Entrepreneurship and Academic Employment - More Alike than You'd Think. Journal of Technology Management \& Innovation, 10(3): 1-10. http://dx.doi.org/10.4067/S0718-27242015000300001

Tasnim, R., \& Singh, H. 2016. "What, Exactly, is Entrepreneurial Commitment?": Modeling the Commitment of Successful Entrepreneurs. Journal of Applied Management and Entrepreneurship, 21(3): 6-35.

https://doi.org/10.9774/GLEAF.3709.2016.ju.00003

Tasnim, R., Yahya, S., \& Zainuddin, M. N. 2014. "I'm Loving It!” What Makes the Successful Entrepreneur Affectively Committed to Entrepreneurial Performance? Journal of Applied Management and Entrepreneurship, 19(2): 27-52.

http://doi.org/10.9774/GLEAF.3709.2014.ap.00004

Visintin, F., \& Pittino, D. 2014. Founding Team Composition and Early Performance of University-Based Spin-Off Companies. Technovation, 34(1): 31-43.

http://doi.org/10.1016/j.technovation.2013.09.004

Vohora, A., Wright, M., \& Lockett, A. 2004. Critical Junctures in the Development of University High-Tech Spinout Companies. Research Policy, 33(1): 147-175.

http://doi.org/10.1016/S0048-7333(03)00107-0

Yin, R. K. 2009. Case Study Research: Design and Methods (4th ed.). Thousand Oaks, CA: Sage Publications.

Citation: Brodack, F., \& Sinell, A. 2017. Promoting

Entrepreneurial Commitment: The Benefits of

(cc) BY

Interdisciplinarity. Technology Innovation Management

Review, 7(12): 6-13.

http://doi.org/10.22215/timreview/1123

Keywords: entrepreneurial commitment, interdisciplinarity, academic spin-offs, technology

transfer, teamwork, team composition 


\section{Academic Affiliations and Funding Acknowledgements}

Canadà
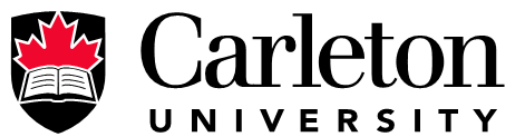

U N I V E R S I T Y

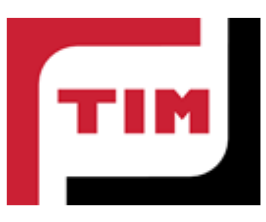

The Federal Economic Development Agency for Southern Ontario (FedDev Ontario; feddevontario.gc.ca) is part of the Innovation, Science and Economic Development portfolio and one of six regional development agencies, each of which helps to address key economic challenges by providing regionallytailored programs, services, knowledge and expertise.

- The TIM Review receives partial funding from FedDev Ontario's Investing in Regional Diversification initiative.

Technology Innovation Management (TIM; timprogram.ca) is an international master's level program at Carleton University in Ottawa, Canada. It leads to a Master of Applied Science (M.A.Sc.) degree, a Master of Engineering (M.Eng.) degree, or a Master of Entrepreneurship (M.Ent.) degree. The objective of this program is to train aspiring entrepreneurs on creating wealth at the early stages of company or opportunity lifecycles.

- The TIM Review is published in association with and receives partial funding from the TIM program. 